and description, or for the work of others designated by me.

(3) At my decease, and forever after, these collections shall be under the charge of the Trustees of the Peabody Museum and their successors, and in the special custody of Curators recommended by them and appointed by the Corporation of Yale University.

(4) The type specimens and others of special importance in these collections shall not be removed from the Museum building. Less valuable specimens, however, especially duplicates, may be so removed by vote of the Trustees of the Museum.

From a scientific point of view, the value of the collections now presented to Yale is beyond price, each one containing many specimens that can never be duplicated, and already of historical interest in the annals of science.

Among the prominent features of one of these collections, that of extinct vertebrates, may be mentioned (1) the series of fossils illustrating the genealogy of the horse, as made out by Professor Marsh, and accepted by Huxley, who used it as the basis of his New York lectures ; (2) the Birds with teeth, nearly two hundred individuals, described in Professor Marsh's well-known monograph 'Odontornithes;' (3) the gigantic Dinocerata, several hun. dred in number, Eocene mammals described in his monograph on this group; (4) the Brontotheridæ, huge Miocene mammals, some two hundred in number; (5) Pterodactyles, or flying dragons, over six hundred in number; (6) the Mosasaurs, or Cretaceous sea-serpents, represented by more than fifteen hundred individuals; (7) a large number of Dinosaurian reptiles, some of gigantic size. Besides there are various other groups of Mammals, Birds and Reptiles, most of them including unique specimens.

The resolutions of the Corporation of
Yale University, accepting Professor Marsh's gift, and showing their appreciation of his services to the University, are given below :

YALE UNIVersity, January 13, 1898.

The President and Fellows having received a deed of gift from Professor Othniel C. Marsh, presenting to the University his very valuable collections now in the Peabody Museum, which represent the labor of many years on his part and also the expenditure of a large amount from his personal fortune, desire, as they accept the gift, to communicate to him and to place on record an expression of their grateful acknowledgment of his generosity.

In this grateful acknowledgment they are confident that all the graduates and friends of Yale will unite, when they learn of this most recent manifestation of his long-continued interest in the University, even as they already fully appreciate the unselfish devotion of his time, his talents and his energies, for more than thirty years, to the scientific researches which have given him such personal distinction and have brought such renown to the institution.

TImothy DWIGHT,

President.

\section{GEOLOGICAL SOCIETY OF AMERICA.}

\section{II.}

Note on Lepidophloios Cliftonensis. SIR WILliam Dawson, Montreal, Canada.

In the Bulletin of this Society for May, 1891, appeared a paper by the author on 'Fossils from the Carboniferous of Newfoundland,' including new species of Lepidodendron ( $L$. Murrayanium). In connection with this species I noticed what seemed a closely allied form from New Brunswick, which I had named $L$. Cliftonense. Later studies of this species have shown me that it should should rather be placed in the allied genus Lepidophloios. I have so placed it in a more recent paper on the genus in the present year. It should, therefore, be named Lepidophloios Cliftonensis, but is one of the species of that genus nearest to Lepidodendron, and especially to my L. Murrayanium and to $L$. Wortheni, of Lesquereux, as I have already stated in the paper to which this note is an addendum and erratum. 
The paper was read by the Secretary. In discussion David White referred to Sir William's long service in paleobotany, he having begun the study of fossil plants in 1843, at the same time with Ettingshausen and Geinitz.

Omphalophloios, a New Lepidodendroid Type. David White.

Mr. White described a Lepidodendron trunk that had been found in the Des Moines series (Lower Carboniferous), at Clinton, Mo. After a review of the forms of the common leaf-scars on Lepidodendrons and an explanation of their functions so far as understood, the peculiar features of the one in question were outlined. The paper requires cuts to make these clear. It was discussed by H. L. Fairchild.

The Mastodon in Western Ontario. H. M.

AMr.

Mr. Ami described the exhuming of two mastodons in Ontario, one in Essex county, north of the west end of Lake Erie, and one in Norfolk county, at the east end of the same lake. In the former case the section of six to eight feet that was dug up involved the following from below upward, at the bottom clay and boulders; then gravel, the bones, sand and shell marl, sand and peat, gray sand, sand and ochre yellow sand. The remains were fragmentary. In Norfolk county the pit was three to four and one-half feet; at the base was clay; then shell marl, mottled sand, gray sand and peat. The skull extended from the clay through the others. In addition, 25 ribs, 40 feet-bones, 2 tusks and many vertebræ were recovered. In the peat deer-bones and arrow-heads were found.

Mastodon and Mammoth Remains found near

Hudson Bay. RoBert Bell, Ottawa, Canada.

The paper gave an account (1) of the discovery of some mastodon bones in 1877 , near the junction of the Mattagomi and
Missinaibi Rivers, to form the Moose River in the southern part of the basin of Hudson Bay, and described the superficial deposits in that region; and (2) of the finding of a peculiarly small mammoth's tooth on Long Island, off the Eastmain coast of Hudson Bay. It discussed the question of the specific identity of this small northern mammoth with the common species of more southern latitudes in North America.

The first mentioned specimen was discovered by an Indian, who chopped out a tooth from a skull lying in the river and then left the latter. The speaker passed the spot at high-water and could not secure the bones. The other was found on the bare rock.

Fossil-like Forms in the Sault Ste. Marie Sandstone. Robert BeLl, Ottawa, Canada.

In the bottom of the pit which was excavated in the sandstone for the canal lock on the south side of the Sault Ste. Marie, in 1891, a bed was found covered with very distinct markings, which in some respects resemble large plant remains, but they are probably casts of desiccation cracks. The author's remarks were illustrated by photographs of four large specimens. The remains were surprisingly like fossils, but all present agreed with the speaker in their interpretation.

Syenite-porphyry Dikes in the Adirondack Region. Henry P. Cushing, Cleveland, $\mathrm{O}$. Recent field work in Clinton county, $N$. Y., has shown the existence of dikes belonging to the syenite-trachyte family of eruptive rocks, which are of different age from the bostonites described by Kemp and Marsters from the near vicinity. They are older than the Potsdam sandstone, as they have furnished pebbles to its basal conglomerate. On the other hand, the older rocks of the region were metamorphosed before their extrusion. Together with the associated diabases they show great resem- 
blance to the Keweenawan eruptives of the Lake Superior region. They possess considerable petrographical interest.

Analyses which were given showed them to be rich in soda and of a composition that would lead one to infer the presence of nepheline, yet none could be detected by chemical or optical tests. The rocks attracted much interest from the petrographers present.

In discussion J.F. Kemp outlined briefly the area in the Champlain Valley in which the smaller dikes were found, stating that they practically ceased near Ticonderoga and were not known in the southwestern Adirondacks. J. P. Iddings mentioned the difficulty of giving an expressive name to the rocks and the curious position that they occupied.

Clastic Huronian Rocks of Western Ontario, and the Relation of Huronian to Laurentian. A. P. Coleman, Toronto, Canada.

The speaker had been led to observe and study the rocks in question while reporting on the gold districts north of Lake Superior for the Ontario government. He reviewed the work of Lawson, H. L. Smyth and others in connection with maps, and described especially the clastic rocks. The distribution of the Conchiching around dome-like areas of the Laurentian crystallines, he suggested, could be perhaps explained by dome-like upheavals or bulgings of the latter, the domes being located where the overlying burden of sediments was thinnest. It was suggested that the same explanation might be applied to mountains elsewhere.

In discussion Robert Bell reviewed the early work of the pioneer observers in the region, and differed from Professor Coleman in his interpretation. G. O. Smith stated that many contacts in the Huronian regions on the south were obscure, but that others were very plain and showed a basal conglomerate resting on the ancient granite.
G. M. Dawson spoke of the importance and difficulty of discriminating between an intruded batholite and a supporting basement of older granite. A. E. Barlow briefly described the breccias, graywackes, quartzites and conglomerates on Lake Temiscaming, and insisted that Laurentian was now only a petrographical and not a time-term. In closing the discussion Dr. Coleman replied in a few words to the remarks that had been made.

The Gnading of Mountain Slopes. W. M. Davis, Cambridge, Mass.

With the lantern Professor Davis threw on the screen a series of views of slopes in various mountain ranges and from areas of other topographic forms and brought out the idea that, unless sapping or some other undermining action is in progress, the surface reaches a slope or grade that expresses the balance established between the weathering forces and the resistance of the materials. This feature is quite pronounced and characteristic and is described by speaking of the slopes as 'graded.' The grades differ according to the materials in'volved, and the evenness of the 'grade' is largely a function of the time of exposure.

The Harvard Geographical Models. W. M. Davis, Cambridge, Mass.

The Harvard Geographical Models, designed by the author and constructed by Mr. G. C. Curtis, have been prepared for the purpose of giving systematic illustration of a number of geographical forms in their genetic relationship. Three of the series were described and exhibited by means of lantern slides. They represent a mountainous region descending to the sea ; the same after depresssion, whereby the shore-line has become very irregular; the same after elevation, whereby a coastal plain has been added to the land area.

The Society then adjourned until the following day. In the evening a reception 
was tendered the Fellows by Mrs. J. B. Porter and Mrs. F. D. Adams in the new McDonald mining laboratories of the University. Many of the faculty families and their friends in the city gathered to welcome the Fellows and a most enjoyable evening was passed. Everything that cordial hospitality could suggest was done for the visitors. The spacious laboratories and their elaborate equipment with machinery of actual working size excited everyone's admiration and should assist in an important way in developing the University and the Dominion.

On reassembling Thursday morning, at 10 a. $m$., the reading of papers was resumed. Nodular Granite from Pine Lake, Ontario. Frank D. Adams, Montreal, Canada.

The paper described a granite from a recently surveyed portion of the Province of Ontario which in places contains an abundance of nodules scattered through it. These nodules differ in a marked manner from any of those occurring in the hitherto described nodular granites, among other things in being more acid in composition than the rock itself. They are frequently found to be arranged in long lines which, when followed up, coalesce into sheets having all the characters which are commonly presented by secondary quartzose veins. The phenomenon evidently results from a process of differentiation in the original magma and has an intimate bearing on the question of the origin of 'Contemporaneous Veins.'

Chemical Composition of the Granite from Pine Lake, Ontario. Nevil N. Evans, Montreal, Canada.

The analyses as given below proved that the cores of the nodules were more acid than the rims, a relation the reverse of that met elsewhere.

J. P. Iddings compared these nodules with spherulites in obsidian, and Whitman
Cross brought out the lack of correpondence between them and the spherulitic phenomena with which he had become familiar. J. F. Kemp emphasized the contrasts with Craftsbury, Vt., 'prune' granite and the orbicular granite at Quonochontogue, R. I.

\begin{tabular}{|c|c|c|}
\hline & Nodule. & $\begin{array}{l}\text { Normal } \\
\text { Granite. }\end{array}$ \\
\hline Loss............................ & 0.92 & 0.32 \\
\hline $\mathrm{SiO}_{2} \ldots \ldots \ldots \ldots \ldots \ldots$ & 81.43 & 78.83 \\
\hline $\mathrm{Al}_{2} \mathrm{O}_{3} \ldots \ldots \ldots \ldots \ldots \ldots$ & 13.70 & 10.88 \\
\hline $\mathrm{Fe}_{2} \mathrm{O}_{3} \ldots \ldots \ldots \ldots \ldots \ldots$ & . 1.58 & 1.63 \\
\hline $\mathrm{CaO} \ldots \ldots \ldots \ldots \ldots \ldots \ldots$ & 0.37 & 0.22 \\
\hline MgO ....................... & 0.06 & 0.35 \\
\hline $\mathrm{K}_{2} \mathrm{O} \ldots \ldots \ldots \ldots \ldots \ldots$ & 1.28 & 5.31 \\
\hline $\mathrm{Na}_{2} \mathrm{O} \ldots \ldots \ldots \ldots \ldots \ldots$ & 1.02 & 2.13 \\
\hline & & 99.67 \\
\hline
\end{tabular}

Experiments on the Flow of Rocks now being made at McGill University. Frank D. Adams and John T. Nicholson, Montreal, Canada.

The paper was presented by Dr. Adams and was illustrated by the lantern, by specimens of the results attained, and by a subsequent visit to the shops to see the machine. The authors have constructed a special crushing machine, much like the usual testing apparatus of engineering laboratories. Their object has been to subject cylinders of various rocks to pressures far above their crushing resistance, yet to confine them so that they could not shatter. After many unsuccessful trials of materials, strips of soft Swedish sheet iron were wrapped around a core of mild steel and welded together. The core was then bored out, the hole carefully polished and given a taper of one in a thousand. These cylinders were about $3 \frac{1}{2}-4$ inches high and were turned down in the outer middle part so as to localize any bulging under pressure to this portion. They, therefore, looked like large spools, with thick ends. Cylinders of Carrara marble had meantime been prepared in Germany of the same taper as the holes and of such a size that, when the spools were heated and expanded, 
the cylinders dropped snugly in and were caught midway of the spool. The cylinders of marble were about two centimeters in diameter. Chrome-steel plungers were employed in the squeeze, and fitted perfectly in the spools. By using the city water mains, which give at the University a pressure of 135 pounds to the square inch, oil was forced in beneath the piston of the press, and cylinder pressure gauges and a recording curve-tracing mechanism were connected. The blocks were gradually compressed until subjected to thirty tons' pressure. Under this squeeze the marble cylinder bulged at the middle, expanded its iron jacket and approximated a thick disc. When released it was found that it had flowed without losing its cohesion at all. When split down the vertical axis the cross section revealed two opposing paraboloids, or blunt cones of unchanged marble, filled in between with a dense, chalky variety, but all perfectly solid. Thin sections show a great abundance of twinning striations and gliding planes and evidences of strain. Cylinders of Baveno granite are now ready for experimentation, but have not yet been compressed. Peat has, however, been compressed into a black, shining and lustrous substance, very like high-grade lignite or coal, a result similar to that obtained abroad. Copper filings have been compacted also to solid metal. A further apparatus has been designed so that superheated steam can be introduced into the test, which can be kept at $500^{\circ} \mathrm{F}$., for months at a stretch, while the compression is progressing, the gauges and recorder meantime registering the pressure at all times. Dr. Adams stated that two and a-half years had been spent in experimenting and six months in getting results.

The Fellows were outspoken in their praise of this work, and it was felt by all to be one of the most important contributions ever laid before the Society. It brings within the domain of experiment some of the obscure proceses of dynamic metamorphism and throws great light on the viscous flow of rocks.

The Geological versus the Petrographical Classification of Igneous Rocks. W Witman Cross, Washington, D. C.

In this paper the aim was to show that much of the confusion in existing sehemes for the classification of igneous rocks arises from wrong ideas as to the relations of petrography to geology. Suggestions were made which it is hoped will be useful both to the geologist and to the petrographer.

Dr. Cross presented a very thorough and philosophic review of the vexed question of nomenclature and classification. The distinction was made between petrography, the descriptive part of the subject, and petrology, the discussion of the at present more or less hypothetical or theoretical views regarding the splitting and variations of magmas, etc. Although no actual scheme was suggested, the general bearing of the paper tended toward the development of one that should give widespread satisfaction.

In discussion J. F. Kemp emphasized the importance of having the larger groups of a petrographical scheme, ones that can be used by the student, the mining engineer and by others engaged with rocks, whereas the finer determinations under these general, working groups might be left to the specialist. Such groups must depend solely on mineralogy and texture.

On the Classification of Igneous Rocks. Jos. P. IdDings; Chicago, Ill.

The paper involved a disćussion of some general principles of classification with special reference to the chemical composition of rocks. The point of greatest interest in the paper was the extremely significant charts that Professor Iddings had prepared on the basis of over 900 analyses. 
The ratios of the molecular equivalents of the alkalies to the silica were used as the ordinates, by which the dot indicating the particular analysis was located on the chart, while the actual silica percentages were employed as the abscissas. Very interesting and suggestive groupings of rocks resulted, and charts were shown that exhibited in a graphic way many peculiar points of composition.

Adjournment was then had for lunch. On re-assembling after lunch the following papers were read :

Concentric Weathering in Sedimentary Rocks.

T. C. Hopkins, State College, Pa.; read by G. O. Smith.

The paper was a brief explanation of four photographs showing concentric structure in shale and fire-clay beds in western Pennsylvania. In some places they show a double concentric structure; one on a large scale, starting from the joint planes and resembling exfoliation; another on a smaller scale, showing flattened concretions of varying sizes.

New Geothermal Data from South Dakota, etc.

N. H. Darton, Washington, D. C.; read by W. B. Scott.

By means of two large scale maps of South Dakota the curious variations in the temperature of the water from the artesian wells of the region were shown. All are warm, but the temperatures differ. Assuming that the temperature of the water indicates the temperature of the rock stratum that yields it, and using this in connection with the depth of the well and the mean annual temperature at the surface, very high rates of increase in depth are shown. They vary from an extreme of 18 feet for $1^{\circ} \mathrm{F}$. west of the Missouri river to 35 feet for $1^{\circ} \mathrm{F}$. at the last point recorded in eastern South Dakota. Belts were marked off according to the gradients 20-25 feet, 25-30 feet and 30-35 feet per degree. This developed a long, narrow east and west belt of relatively low gradient, projecting westward into the areas of higher gradient, and corresponding to the nearness to the surface of one of the lower geological formations. The maps are, however, necessary to make the relations clear.

Note on an Area of Compressed Structure in Western Indiana. George H. Ashrex.

This paper was read by J. J. Stevenson. It emphasized the great lack of any evidences of disturbance throughout Indiana, as the geology of the State presents remarkable regularity of strata. Recently, however, the author had found near Asherville, in the block coal region, a great number of small faults, some even reversed, and cited them as evidence of local compression.

Niagara Gorge and St. David's Channel.

Warren Upham, St. Paul, Minn.; read by T. C. Chamberlin.

Having recently again examined the Niagara falls and gorge, with especial reference to the older channel of St. David's, the author believes that a most important element in the history of the gorge erosion has been overlooked by some observers, and that by others its evidences have been misunderstood. This paper shows that the small preglacial stream which eroded the St. David's and Whirlpool channels, having a great depth beneath the river in the Whirlpool, must have flowed for a considerable distance, before reaching that depth, in a gradually widening and deepening ravine, coinciding with the present gorge along the Whirlpool rapids. Because the Niagara River found there a drift-filled narrow ravine, which is cut to the present size of the gorge, its erosion took place in that part by rapids and cascades. Southward from the head of the old ravine the river has eroded its gorge by a great vertical cataract, under which the masses of the Niagara limestone, rolled about by the 
power of the waterfall, have worn the river bed to a maximum depth of nearly 200 feet beneath the water surface.

The narrowness of the gorge along the Whirlpool rapids is therefore attributed to the conditions of the river erosion here indicated, rather than to decrease of the volume of the river by diversion of the water of the upper lakes to flow from Lake Huron eastward. Studies of the glacial Lake Agassiz convince the author that the progress of the epeirogenic uplift of the northern United States and Canada from the Champlain depression was too rapid to accord with the hypothesis of any outflow from Lake Huron toward the east during the long time that would be required for the Niagara River, while thus diminished, to erode the gorge along the Whirlpool rapids. The explanation here given accords mainly with Dr. Julius Pohlman's discussion of the Niagara history, but differs concerning the age of the river and of postglacial time, which is estimated, as from Professor N. H. Winchell's discussion of the Falls of St. Anthony, to have been between 5,000 and 10,000 years.

The Princeton Expedition to Patagonia. W.

B. Scott.

Professor Scott gave an outline of the remarkably rich finds made by the Princeton expedition, whose gatherings already amount to 20 tons and include 1,000 skulls. Mr. Hatcher is again on the ground and will remain three years. The results at present reached show that much revision is necessary of the Argentine stratigraphy as at present published. The lowest beds examined, constituting the Patagonian a marine formation, are Oligocene or lowest Miocene and are equivalent to the Miocene of New Zealand. The overlying Santa Cruz beds of volcanic ash, possibly lacustrine, are not older than the middle Miocene. The upper series or Cape Fairweather beds are Pliocene. All the fossils are in great contrast with those of North America, and the investigator finds himself in a new world. They show foreshadowings of the present South American types. Notwithstanding the incomplete stage of the investigation, many details were given by the speaker which were of the greatest interest to the Society.

The following papers were read by title:

Location and Form of a Drumlin at Barre Falls, Mass. William H. Niles.

Drift Phenomena of the Puget Sound Basin. Bailey Willis.

Notes on the Geology of the Rocky Mountains of Montana. WALTER H. WEed.

Weathering of Alnoite in Manheim, N. Y. C. H. Sмyтt, JR.

On the Occurrence of Corundum in North Hastings, Ont. A. E. Barlow.

The regular business of the meeting being concluded, the Society passed resolutions of thanks for the extremely hospitable reception that it had received from the resident Fellows, especially Professors Adams and Porter, and from the authorities of McGill, and then adjourned. In the evening the usual banquet was held in the Windsor Hotel and proved a very enjoyable conclusion of the exercises of the week.

All the visitors were greatly impressed by the new buildings and fine laboratories of McGill, and repeatedly expressed their appreciation and admiration for the gifts of Mr. McDonald, who has been largely responsible for the recent expansion. The advance of one university is a stimulus and an encouragement for all.

COLUMBIA UNIVRRSTTY.

$$
\text { J. F. KEMP. }
$$

IOWA ACADEMY OF SCIENCES.

THe twelfth annual session of the Iowa Academy of Sciences was held on December 27 and 28, 1897, with Professor T. H. 